\begin{tabular}{|l|l|l||}
\hline \multicolumn{2}{|c|}{ PublisherInfo } \\
\hline \hline PublisherName & $:$ & BioMed Central \\
\hline \hline PublisherLocation & $:$ & London \\
\hline \hline PublisherImprintName & $:$ & BioMed Central \\
\hline \hline
\end{tabular}

\title{
An inchworm unwinds
}

\begin{tabular}{||l|l|l||}
\hline \multicolumn{2}{|c|}{ ArticleInfo } \\
\hline \hline ArticleID & $:$ & 3690 \\
\hline \hline ArticleDOI & $:$ & $10.1186 /$ gb-spotlight-20000526-02 \\
\hline \hline ArticleCitationID & $:$ & spotlight-20000526-02 \\
\hline \hline ArticleSequenceNumber & $:$ & 127 \\
\hline \hline ArticleCategory & $:$ & Research news \\
\hline \hline ArticleFirstPage & $:$ & 1 \\
\hline \hline ArticleLastPage & $:$ & 2 \\
\hline \hline & $:$ & RegistrationDate : 2000-05-26 \\
ArticleHistory & $:$ & OnlineDate $\quad$ 2000-05-26 \\
\hline \hline ArticleCopyright & $:$ & BioMed Central Ltd2000 \\
\hline \hline ArticleGrants & $:$ & \\
\hline \hline ArticleContext & $:$ & 130591111 \\
\hline \hline
\end{tabular}




\section{William Wells}

Email: wells@biotext.com

In the 18 May Nature, Blanco and Kowalczykowski report on the motions of the RecBC DNA helicase, a protein that unwinds DNA strands during homologous recombination in Escherichia coli. The helicase needs a double-stranded blunt end to load onto DNA, but can then move along a single strand from 3' to 5'. A large gap in this strand causes the helicase to fall off. If the gap is shorter, however, the helicase leaps over the gap (Nature 2000, 405:368-372). By varying the length of the initial double-stranded section and the subsequent single-stranded gap, the researchers show that the helicase moves in approximately 23 -nucleotide steps from its point of loading. A helicase that initially traverses 31 nucleotides of double-stranded DNA, for example, can subsequently jump a gap up to a maximum of 15 nucleotides in length. Blanco and Kowalczykowski propose that the helicase domain catches up to the leading binding domain in multiple steps of 2-5 basepairs each.

\section{References}

1. Nature, [http://www.nature.com/nature/]

2. Helicases: a unifying structural theme?

This PDF file was created after publication. 